I. ROZPRAWY I ANALIZY

DOI: $10.17951 /$ et.2015.27.63

Irena Vă̌ková

(Prague)

\title{
VÁNOCE 'CHRISTMAS' IN THE ETHNOLINGUisTiC PERSPECTIVE. CZECH KEY WORDS AND VALUES
}

The paper introduces a pilot study from ongoing ethnolinguistic research into the Czech concept of VÁNOCE 'Christmas'. It is placed in the context of the theory of cultural key words referring to the author's previous studies on the concepts of DOMOV 'home, homeland' and POHODA 'well-being, comfort, rest, peace'. In the paper, the meaning of the concept of VÁNOCE is summarized in accordance with Czech monolingual dictionaries, the rituals and scenarios associated with the Christmas Eve are described using empirical research data, analysed are social discussions of Christmas (esp. of the baby Jesus) as well as examples of the conceptualization of Christmas in popular songs. The paper also includes several remarks on the Christmas stereotype in Czech sign language.

KeY Words: Vánoce, Christmas, values, Czech, Czech culture, cognitive ethnolinguistics, cultural key words, Czech sign language

... And the bells are ringing, lights are burning -

Oh Christmas! Oh Christmas!

Jaroslav Vrchlický, Vánoce. Translated by Ondřej Hanus for the purpose of this paper. Co żivot dal, Praha 1883 
We are trying to preserve traditional Czech Christmas and its customs. We want to save the Baby Jesus from the fatso in red and his goggle-eyed reindeer flunkeys. In the past, the Russians made us celebrate Father Frost, and twenty years after the velvet revolution, Santa Claus is trying to overtake his spot. But in our country, the Baby Jesus is the one who brings Christmas presents. That is why we appeal to the public and everyone who loves Czech Christmas: Sign the petition and save the Baby Jesus.

http://www.zachrantejeziska.cz/

\subsection{Introduction: research context}

The celebration of the winter holidays is deeply rooted in European civilization. It dates back to the pre-Christian, magic-related interpretation of time based on astronomical reality (experienced anthropocentrically and geocentrically), namely "winter solstice", as well as to the Christian concept ("the birth of Christ"). ${ }^{1}$ Throughout the centuries, the character of the winter holidays has changed and culturally diversified ${ }^{2}$ in different nations, which has also been reflected in their languages. "Vánoce", therefore, can be considered a specifically Czech holiday.

${ }^{1}$ The four major rituals held by old Slavs (and their neighbours) relating to the "significant rhythms of the year, such as winter and summer solstice, arrival of spring, and the summer harvest", determined by "the apparent movement of the Sun throughout the year". Originally, these celebrations had an economic dimension; the magic was supposed to influence natural laws, guarantee a successful harvest, and ensure that the world order with all its cycles remained unchanged etc. In the early medieval references, kračun (the celebration of the shortest day of the year) and koleda (originally the act of walking around with a baby figurine symbolizing the newly born Sun) were mentioned in the context of the Slavic winter solstice holidays (see Ván̆a 1990: 205). After the arrival of Christianity, these celebrations merged with the religious holidays; however, they preserved their pagan character long after that. For the "magical time circle" of the Slavs from the ethnolinguistic perspective see Tolstoj (2003).

${ }^{2}$ Recently, on the other hand, it has been evident that globalization and unification processes have influenced the character of Christmas. However, sometimes they provoke an opposite reaction: an effort to preserve the traditions of the national community (e.g. the initiative to save the baby Jesus, see below).

${ }^{3}$ The differences can be found in the motivation of its name: it refers to the birth (Latin Natalis and similar expressions in Roman languages, but also the Russian expression rožděstvo, Ukrainian rizavo or Polish Boże Narodzenie), to Christ (English Christmas,

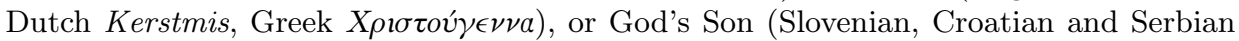
$B o z ̌ i c ́$, Macedonian Božik). In other languages the conceptualization is inspired by old pre-Christian rites (Bulgarian koleda, Belarussian kaljady, Hungarian karácsony, Romanian krăčun - see footnote 1). The Czech expression Vánoce (and Slovak Vianoce) is etymologically linked with the German Weihnachten; when it was borrowed, however, is not clear (according to Machek 1997, it is an old loan from the period before the arrival 
Today, we can distinguish three organically interconnected historicalcultural layers in Czech Christmas: the folk, pre-Christian layer (the celebration of winter solstice with many pagan customs and fortune telling), later followed by a Christian layer referring to the birth of Christ (hence the Bohemian and Moravian traditions of nativity-scene making, the music of Czech teachers - so called pastorales, popular Christmas plays etc.), and finally the bourgeois layer, which originated in the wake of the industrial revolution (migration of people from villages to cities, the expansion of the bourgeoisie). These changes contributed to the secularization of Christmas, which then resulted in the celebrations being moved from the churches to people's homes, and in emphasizing the gift-giving aspect of Christmas. This trend spread from municipal households to villages (for more information see Frolec 1988: 17ff.). Today's symbol of Christmas, the Christmas tree, dates back only to the $1^{\text {st }}$ half of the $19^{\text {th }}$ century (see Vavřinová 2002: 115). The Czech writer Božena Němcová introduced it as a new custom in a Christmas scene in her novel Babička/The Grandmother. At the same time, this novel also describes (similarly to Kytice/Wild Flowers by K. J. Erben, see below) old customs of money-related and fortune-telling magic practices. Some of them are used even today, albeit in the form of a game, see further (for more detailed information see Brouček and Jeřábek, I, 2007: 1107ff.). However, the modern Christmas celebrations also include much younger traditions (Christmas dishes, watching certain TV programmes, etc.).

Contemporary celebration of Christmas, which is undoubtedly considered the most important holiday of the year, focuses primarily on home and family. A vast majority of the Czech population (albeit greatly secularized) still perceives the Christian aspect of Christmas ${ }^{4}$ (see the Baby Jesus figure bringing presents). At Christmas, esp. on Christmas Eve, many people pay a visit to church (for many, this is the only time in the whole year), even though they do not consider themselves believers; the respondents often claim to attend the traditional Midnight Mass or to go and see the church nativity scene with children.

Nowadays, Christmas celebration combines many rituals of different origin and character; however, in the naive picture of the world, these usually merge. Currently, its most emphasised aspects are that of FAMILY WELL-

of Cyril and Methodius; however, Rejzek (2001) offers counter-arguments). The first part refers to weihen 'sanctify', the second one to Nacht 'night'.

${ }^{4}$ Easter, on the other hand, is generally perceived as the "spring holiday", not as the Christian holiday celebrating the crucifixion and resurrection of Jesus Christ. 
BEING (see below), ABUNDANCE, and GIFT GIVING. ${ }^{5}$ The Christmas issues of lifestyle or women's magazines usually highlight the concept of POHODA 'well-being, comfort, rest, peace', frequently depicted in advertisements, Christmas-themed home decorations, the preparation of holiday dishes, and ideas for suitable presents. However, many alternative sources criticize this interpretation of Christmas for its focus on consumerism, which is in strong contradiction to the "real Christmas". Christmas is a topic of social discussion (see below), the real stereotype of Christmas ("what Christmas usually looks like") frequently being contrasted with the ideal stereotype ("what Christmas should look like"). ${ }^{6}$ Some critics point out the lack of spiritual values in today's Christmas celebrations, others stress the family aspect of Christmas ("what no money can buy"), such as a loving home, close relationships, and love among family members (demonstrated by spending time together, not by giving each other expensive presents). Similar discussions have also, however, become a part of the Christmas stereotype.

Even in contemporary secularized Czech society, there is a need for sacred experience, sacrum, and it is Christmas that plays an exceptional role in this regard (even though Czechs tend to reflect it by means of travesty or parody). The current emphasis on home in celebrating Christmas does not exclude the sacrum; home and family (or even a larger community) are closely linked to traditions and rituals that serve as a basis for experiencing the sacred.

In language, the concept of VÁNOCE is closely linked to the concept of DOMOV and POHODA as was demonstrated in our previous research (see below). As we will see, this is a field associated with the study of values of a community via language and texts - in the context of a cognitivelyoriented ethnolinguistics (see Bartmiński 2007, etc.).

However, this is only the beginning of intensive, collective research on Czech Christmas (for more information on the ethnolinguistic-didactic project carried out by a group of postgraduates and lecturers from two Czech linguistic departments at Charles University in Prague see Wildová forthcoming). The objective of this paper is merely to present the groundwork for further research, while explaining why we believe Vánoce belongs to the

${ }^{5}$ This aspect is often used in advertising. For example, the Alza e-shop (www.alza.cz) created an advertising campaign Summer Christmas, cf. a newspaper advertisement Are you ready for the Summer Christmas?, which introduced special offers on tablets, cameras etc., or a TV spot with the company mascot singing a modified version of Jingle bells with promotion lyrics.

${ }^{6}$ For the difference between a "typical" and "real" (true, ideal) representative of a category, see Bartmiński (2009: 157), referring to the Polish stereotype of a mother. 
semantic group of key words. We will present only several minor examples from the main areas of our research (see also Vaňková forthcoming).

\subsection{Christmas in the ethnolinguistic perspective}

The expression Vánoce, referring to the most important Czech holiday, comprises a semantically complex and multi-layered concept. Changes in celebrating Christmas as well as its reflection in different areas of social life have generated many different connotations of Vánoce. The aim of our research is to try to describe this complex network of connotations as a clear and transparent structure and characterize the stereotype of Czech Christmas (for the concept and methods of studying stereotypes see Bartmiński 2007). Observations based on linguistic, textual, and empirically obtained material may also help us reveal the specific nature of the Czech linguisticcultural worldview. The language (together with other parallel, languagerelated cultural $\operatorname{codes}^{7}$ ) reflects not only the stereotype of Christmas, but also other values that are significant and, compared with other languages and cultures, highly specific for Czech society.

As the following analyses show, this stereotype, on the most general level, takes the form of a scenario and covers many other, more specific stereotypes referring to particular actions (e.g. the scenario of the Christmas Eve dinner, gift unwrapping, lead pouring), objects (e.g. the Christmas tree, Christmas sweet bread) or an abstract phenomenon, such as the experience of Christmas pohoda 'well-being'.

The phenomenon of Christmas is undoubtedly interesting for many fields within the humanities (history, ethnology, folklore studies, culture studies etc.); in recent years, several Czech monographs and studies were published on the subject Christmas and its origins, history, celebration, or customs (apart from the ones mentioned above see also Frolec 1988, Kourovi 2010, Navrátilová 2003, Vavřinová 2002, Večerková and Frolcová 2010). The specific nature of our ethnolinguistic approach and its possible contribution to and interaction with other approaches will be introduced in the following sections.

7 These are secondary modelling systems, as described by Lotman, i.e. superstructural systems that are above the level of natural languages, esp. mythology, religion, but also arts - both verbal and nonverbal (Lotman 1990). 


\section{The study of values and Czech cultural key concept-words DOMOV 'home, homeland' and POHODA 'well-being, comfort, rest, peace'}

To be healthy, peaceful, happy

Is our wish to you,

This is what we wish you, father,

And your children, too...

(Traditional Czech Christmas carol Štěstí, zdraví, translated by Ondřej Hanus for the purpose of this paper, see also Karel Jaromir Erben, Prostonárodni české písně a řikadla, Praha: Evropský literární klub, 1937: p. 42)

But no, mama was here again and suddenly said:

Christmas! - even though, in fact, she'd been saying it all year long...

(Holan 1988, A Night with Hamlet)

Peaceful Christmas: This year, turn off stress, turn on Czech TV!

Well-known traditions, but also new surprises under the Christmas tree - both belong to the most wonderful time of the year at home as well as on TV. As a Christmas present for you, there will be plenty of your favourite classics as well as new movies - get excited for two brand new Czech fairy tales. This year, it's all about peaceful Christmas on Czech TV. Start unwrapping on December 19 and do not stop until January 6.

http://www.ceskatelevize.cz/ct24/kultura/249892-svatky-na-pohodu-o-vanocichvypnete-zapnete-jen-ceskou-televizi/

All of the above-mentioned extracts reflect the values contributing to the Czech conceptualization of Christmas. The first one is the opening lines of an old and well-known Czech Christmas carol in which carollers going around the neighbourhood wished health, peace and happiness to everyone, clearly referring to values appreciated in those days by carollers as well as their listeners. ${ }^{8}$

${ }^{8}$ Regarding the linguistic study of values, Bartmiński suggests focussing on text types with value-oriented intention: dream books, horoscopes, or Christmas and New Year's carols and greetings. If we analyse what people wish one another in such texts, we may reveal the specific axiological system of a given community (Bartmiński 2010). In this context we could focus on Czech texts in Christmas cards (sending Christmas cards has been a tradition all over Europe for more than 150 years, see Vavřinová 2002: 170). This genre has the form of a set phrase expressing that "someone wishes something to someone else". Based on our own communication experience, the following expressions may stand for the "something" in Christmas cards: krásné 'beautiful', hezké 'nice', veselé 'merry', radostné 'joyful', štastné 'happy', but also pohodové 'relaxed', klidné 'peaceful', or požehnané 'blessed' Christmas (some people add hodně dárků 'many presents' or bohatého ježiška 'generous Baby Jesus' etc.). At the same time we also wish zdravi 'health', štěsti 'luck', spokojenost 'happiness', (rodinnou) pohodu '(family) well-being' or hodně úspěchũ 'many a success', (Boží) požehnáni '(God's) blessing' in the New Year (with 
In his poem A Night with Hamlet, the famous Czech poet Vladimír Holan associates Christmas with his mother. Similarly to Jaroslav Seifert's poetry, in Holan's texts maminka 'mother' represents one of the few indisputable values, she is sacralised and celebrated as the embodiment of good and love, hence saying it all year long in the extract. Christmas symbolizes blissful memories of childhood and shares similar connotations with mother.

The third, most recent text, advertises TV programmes broadcasted during Christmas. Linguistically, the advertisement draws on colloquial discourse, as in the informal phrase svátky na pohodu 'it's all about peaceful Christmas', or the verb vypnout 'turn off the stress', meaning 'to do nothing and relax', used as a pun in contrast to zapnout 'turn on Czech TV'. The text emphasizes the concept of POHODA 'well-being, peace', in pohodové Vánoce 'peaceful Christmas', and gift giving (TV programmes are metaphorically conceptualized as presents wrapped under the Christmas tree).

According to surveys of life values of Czech citizens, "family" ranks first, "friends and acquaintances" second and "free time" third. "Job" occupies the fourth position, with "politics" and "religion" following at a significant distance (Prudký et al. 2009). At the same time, the importance of "free time" and "friends and acquaintances" has been consistently on the rise since 1991, while other values keep dropping. The importance of "family" has been decreasing, too, despite the fact that it still occupies first place in the value system.

Long-term preferences of "hedonistic" values, highlighted by Czech sociologists, have also been confirmed by research within the ethnolinguistic context, namely by studies based on analysing so-called cultural key words (Wierzbicka 1997), or rather related concepts, such as DOMOV 'home, homeland' (Danaher 2010, Vaňková 2012a,b), KLID 'rest, peace' (Danaher 2010), and especially POHODA 'well-being, comfort, rest, peace' (Vaňková 2010). We should also point out studies of other lexical and grammatical devices expressing "self-indulgence" (e.g. the use of the dative case indicating comfort and benefit), which do not have an equivalent in other languages. These devices enable an interesting interpretation of Czech culture (see Janda 2007).

In this connection, it is necessary to mention the international project EUROJOS, which is focuses on the comparative analysis of "the values

many variations or updates; however, in this type of research, that which is repeated is what matters most). It would be interesting to conduct research oriented on the quality as well as the quantity of expressions used in well-wishing (e.g. with respect to the age of respondents in the communicative situations), which would indicate what we actually wish and possibly are not aware of. 
of the Slavs and their neighbours" (see Bartmiński 2010). Its objective is to compare and analyse corresponding concepts connected with values in different languages (e.g. DОМ/ДОМ/DOMOV etc., see Abramowicz, Bartmiński and Bielińska-Gardziel 2012). Czech linguistic and textual material indicates a connection between the concepts DOMOV and POHODA (pohoda domova 'homely well-being') and at the same time opens new possibilities for the study of a specifically Czech hedonism as demonstrated in the Czech language (Vaňková 2010, 2012a, b).

The concept of DOMOV has, however, different meanings and only some of them are linked to hedonism (well-being, comfort, rest)..$^{9}$ In this regard, the concept of VÁNOCE is perhaps similarly complex. Our aim is to prove that it is one of the so-called key words of contemporary Czech culture and that it belongs to the same semantic framework as DOMOV or POHODA.

\section{Vánoce in the Czech language and in Czech monolingual dictionaries}

Ježišek, -ška m. 1. zdrob. k Ježǐš: figurka J-a v jesličkách 'the Baby Jesus in the nativity scene' (... 2) 2. Štědrý večer 'December 24', den: dát, dostat dárek $k J-u$ 'give, get a Christmas present'; na J-a padal sníh 'it was snowing on December 24' na Štědrý den, o Vánocích; - ježı̌šek, -ška m. štědrovečerní dárek, nadílka: dostat bohatého $j$ - a 'get plenty of Christmas presents' (the dictionary entry for Ježišek 'the Baby Jesus' in SSČ 1994)

The study of stereotypes in the linguistic perspective is based on language (systemic) data; we draw on the relevant entries in monolingual and other dictionaries that provide evidence of how fixed the analysed features are in language. ${ }^{10}$ First, we will focus on the lexicographers' reflections that

${ }^{9}$ For the semantics and the profiles of the concept DOMOV see Vaňková (2012a, b), for POHODA see Vaňková (2010). The two semantic aspects of home are reflected already in Josef Jungmann's dictionary: 1) "where sb. lives, resides", and 2) "where sb. was born" (Jungmann 1989), e.g. the profile of a place of living and the profile of a birthplace. The first one is connected with privacy, personal life, and closely-related people - partners and family, and also with free time, comfort, and well-being. This leads to the semantics of the key word POHODA (contexts in which it is associated with DOMOV are very frequent - see Vaňková 2010, 2012b). The concept of VÁNOCE is strongly associated with this profile of DOMOV (with the aspect of living, free time, comfort, well-being) as well as with its second profile: the birthplace. Especially adults and elderly people often associate Christmas with memories of childhood and Christmas celebrations in their original family.

${ }^{10}$ For the linguistic data that are the basis of verifying connotations (with the aim of reconstructing stereotypes), cf. Bartmiński, 2007. 
take the form of semantic definitions of the Vánoce lexeme, including accompanying example sentences, and on some specific expressions from the semantic framework of "Christmas".

The word Vánoce frequently conveys the meaning of a simple time specification (referring to a period or turning point), e.g. in the saying Zelené Vánoce, bilé Velikonoce 'Green Christmas, White Easter', or in phrases like do Vánoc musi být text odevzdán 'the deadline for the text submission is Christmas'. In the Reference Dictionary of the Czech Language (Příručni slovnik jazyka českého, PSJČ 1935-1957), the first described meaning of the lexeme vánoce (written with the small letter in accordance with the orthographic rules at that time, similarly to the Dictionary of Standard Czech Language, SSJ $\check{C}$ 1958-1971)11 refers to the time period: "the period covering the Catholic holidays as well as work days from Christmas Eve to Three Kings' Day, as shown in the examples: Čas ubíhal a vánoce se bližily 'Time went by and Christmas was coming'; Minuly vánoce 'Christmas went by'; Okno zář́ jasně mrtvou noci jak okno kostelni posvátné o vánoci 'The window shines through darkness bright like the church window on a holy Christmas night'; Starý Hrabec chřadnul a před vánocemi umřel 'The old Hrabec languished and died just before Christmas'; Do Prahy jel mladý kniže, před vánoci bylo 'A young prince went to Prague, 'twas before Christmas'; Bylo již po vánocích 'Christmas was over'; Sedláci radostně svědčili, že se dá čekat vskutku úrodný rok podle staré pranostiky: světlé vánoce, tmavé stodoly 'Farmers merrily agreed that it was to be a fertile year according to the old saying: light Christmas, dark barns'. The reference to another semantic frame of Vánoce, i.e. a holiday celebrated in a specific way, is annotated with the qualifier cirk. ('religious'), which specifies it as exclusive, not common. Another semantic frame rather questionably defines Christmas as a "Christian holiday celebrating the birth of Jesus Christ on December 25, and Christmas day"; this meaning is not accompanied by any examples in the dictionary, probably because it could not be interpreted according to the official ideology.

The definitions from $S S J \check{C}$ and $S S \check{C}$ (Dictionary of Standard Czech) clearly reflect the tendency to secularize Christmas, as well as the lack of lexicographers' confidence in how to capture the semantics adequately: "A Christian holiday (December 24-26) celebrating the birth of Jesus Christ, today connected with gift giving (even without the religious background)" (SSJC) ; "a traditional (originally Christian) holiday (December 24-26) connected with gift giving" $(S S \check{C})$.

${ }^{11}$ However, it must be noted that the last volume of $P S J \check{C}$ was published in 1957. 
Probably the most accurate definition of Christmas can be found in the Dictionary of Contemporary Czech (Ssouč Č 2011): "a traditional Christian holiday celebrated to commemorate the birth of Jesus Christ, connected with gift-giving on Christmas Eve (December 24)". This definition emphasizes traditions, the Christian origin of the holiday (the birth of Jesus Christ), gift-giving, and finally Christmas Eve as the most important day of Czech Christmas. The examples include dostat $k$ Vánocům/na Vánoce dárek 'receive a Christmas gift' and the most typical wish Veselé Vánoce a štastný nový rok 'Merry Christmas and a Happy New Year'. The dictionary entry also includes a newer phraseme (a frequent one, but mentioned here for the first time) mít (z čeho) (druhé) Vánoce 'have (second) Christmas' = 'be excited and happy (about something)'. The entry of the adjective vánočni 'Christmas' includes the most common collocations: vánočni koledy 'Christmas carols', péct vánočni cukrovi 'bake Christmas cookies', vánočni svátky/trhy/ozdoby 'Christmas holiday/markets/decorations', vánočni stromek 'Christmas tree', Boži hod vánočni 'Christmas day' (December 25) and botanical name vánoční hvězda/růže 'Christmas star/rose'. This data is significant for the Czech picture of Christmas.

The dictionary entry quoted at the beginning of this section refers to the specific anthroponym (or rather a hypocoristic expression) Ježı̌šek 'the Baby Jesus' (in a secondary, metonymical sense written with a small letter ježišsek). Ježišek means primarily the Baby Jesus, but also a traditional figure who brings Christmas gifts to children (originally representing the gifts that God gives us). ${ }^{12}$

In a metonymical extension, the expression Ježišsek refers to Christmas Eve (or even Christmas as a whole) or to Christmas presents (Už máš pro děti ježı̌ška? 'Have you got the *Baby Jesus for the kids yet?' - Př ejeme veselé Vánoce a bohatého ježiška 'We wish you a merry Christmas and a generous *Baby Jesus'). Even adult Czechs use the expression od ježišsa 'from the Baby Jesus' when they describe what they found under the Christmas tree or when they express gratitude for the presents they receieved ("Thank you, Baby Jesus").

Regarding Christmas gifts, the verb nadělit/nadělovat "give (Christmas) presents" and noun nadilka '(Christmas) giveaway, gift-giving' are semantically specific in Czech: they are primarily related to the gift-giving on Christmas Eve or St. Nicholas Day (December 6). In the $S S J \check{C}$, the verb naděliti is described in the basic meaning as "to give, donate, bring presents,

${ }^{12}$ For the origins and forms of gift-giving customs and for information on "extraterrestrial gift-givers" in Europe, including the specifically Czech image of Baby Jesus as the gift-giver, see Večerková and Frolcová (2010: 277-308). 
most often in connection with Christmas traditions" (with an ideologically characteristic example Děda Mráz nadělil chlapci koloběžku "Ded Moroz = Father Frost brought the boy a scooter"). The secondary meaning is described as "(ironically) cause, make something unpleasant", or "(ironically) surprise sb. in an unpleasant way" in $S S \check{C}$.

According to the Czech National Corpus database (SYN2000), the most common collocation for the noun nadilka, which is semantically defined in a similar manner, is sněhová nadílka 'a lot of snow' (Sněhová nadílka se bližri, Česko čeká ochlazení 'We are expecting heavy snowfall and low temperatures in the Czech Republic'). The phrases mikulášská and vánočni nadilka 'St. Nicholas and Christmas gift-giving', which contain the semantically primary meaning, are less frequent. See also the newspaper headlines Rocková nadílka od Tř́ sester 'Rock music *giveaway from Tři sestry and Divokej Bill' (referring to popular Czech music groups), Letní nadílka $k$ fotoaparátům Samsung 'Summer * giveaway with Samsung cameras' or Vánoční nadílka od prezidenta Zemana 'Christmas * giveaway by the president [Miloš] Zeman' in the article about a presidential speech. Quite frequently, the noun is used in phrases such as Nadilka v ulicích aneb nezodpovědni pejskaři ('Unpleasant surprise in the streets - irresponsible dog owners') referring to animal excrement in the streets (in accordance with one of the meanings of nadělit stated above).

Hopefully, this introductory summary of the linguistic (systemic) data and of their linguistic reflection will suffice for now. However, it will be necessary to obtain and methodically analyse more data in the future (cf. the studies on POHODA and DOMOV, see Vaňková 2010, 2012a).

\section{Christmas and rituals: Christmas Eve scenario}

Cultural metaphors, and the values entailed by them, are propagated by ritual. Ritual forms an indispensable part of the experiential basis for our cultural metaphorical systems.

(Lakoff and Johnson 2008 [1980]: 234)

Hey there, feast of Christmas Eve,

Full of mystery,

What good gift to each will you

Bring in memory?

The landlord gets a Christmas loaf;

Cows, scraps from our plates;

Garlic for the cockerel,

Peas for all his mates. 
To the fruit-tree, fish-bones left

After supper fall;

And those who keep the fast will see

Gold pigs on the wall.

(Karel Jaromir Erben, Štědrý den / Christmas Eve, 2013: 117)

According to Lakoff and Johnson (2002: 234), "[t]here can be no culture without ritual". Together with metaphoricity as a basic conceptualization principle, they point to the cognitive-psychological dimension of ritual in relation to a human individual as well as to society. "We are looking for personal metaphors to give coherence to our life" and we integrate them in rituals, because personal as well as social rituals "give structure and significance to our activities, minimizing chaos and disparity in our actions" (ibid).

Unlike personal rituals, the rituals connected with celebrating holidays are widely shared, and therefore have a social and cultural character. A specific model of celebrating Christmas (based largely on $19^{\text {th }}$ century literature) is depicted in a number of literary works. One of the most prominent examples is the ballad Christmas Eve from Erben's collection of poems Wild Flowers. In this work, Erben combined various aspects of Christianity with the old Slavic model of the world and its concept of order, its tendency to assign specific meanings to certain things and actions, and the necessity to perform acts of magic. Wild Flowers have become a canonical, widely shared text with certain lines from Christmas Eve (and the concepts included in them) functioning as emblematic, esp. those referring to the magical semiotics of Christmas (see Vaňková 2011). Another example is The Grandmother by Božena Němcová, where the celebration of Christmas is directly thematised together with the transformation of traditions (for the genesis of this part of the novel, which was largely inspired by the study of the celebration of holidays by H. J. Hanuš, see Janáčková 2001: 79). ${ }^{13}$

The experience of the sacred (sacrum), which is very important for both individuals and society, has been frequently associated with a specific perception of time. It is not only the long period of preparation prior to the holidays. "The nature of sacred time", says Mircea Eliade, unlike the profane time perceived linearly, is "cyclic, repeatable"; it is the "primordial mythical time made present". Every religious holiday is based on "reactualization of a sacred event that took place in a mythical past, "in the beginning'" (Eliade 2006: 48). In participating in the holiday celebration, people "detach

${ }^{13}$ Cf. other literary descriptions of Christmas in other texts with ethnographic and folkloristic features, such as the chronicles A Year in the Country by the Mrští brothers (1903-1904) or Chodsko Trilogy by Jindřich Šimon Baar (1923-1925). 
themselves" from profane time and magically re-enter the sacred event: the Baby Jesus is "born again" every Christmas. "In every re-enacted holiday, we find ourselves in the same sacred time of last year's holiday or a holiday a hundred years ago" (ibid.). In every celebration of Christmas, the holiday from our childhood, from the last year or from the year before last are made present; we return to the same ways and scenarios of celebrating and re-enact the (same) sacred time.

As stated above, Christmas represents the most important and emotionally prominent holiday for contemporary Czechs. There needs to be a special reason for not celebrating Christmas; ${ }^{14}$ people try to celebrate it at least symbolically even in difficult or non-standard life situations (such as prison, war, homelessness etc.), as described in many works of art and stories of people who experienced these situations (see Kourovi 2010). Only a few objects or acts are necessary to simulate the Christmas Eve celebration: a spruce twig, a burning candle, singing a Christmas carol, or giving a small gift to another person.

Despite the fact that the Catholic Church declared Christmas Day (December 25) the official day of birth of Jesus Christ and that Christmas officially begins at midnight on December 24, it is December 24, Štědrý den (the day before Christmas day), which became the central and most important day of Christmas in the Czech Republic. Štědrý večer (Christmas Eve) is especially prominent, being associated with magical practices and experiencing the sacred (see below). ${ }^{15}$

According to the SSJČ, the adjective štědry' 'generous' means "somebody who likes to give, donate" (the opposite is lakomy 'mean, greedy'); a host or donor can be described as štědrý. The meaning can be transferred to other referents (mit štědrou ruku 'have a generous hand', země je štědrá 'the land is generous') describing them as "plentiful, rich, abundant" (štědré dary 'plentiful gifts'; štědrá úroda 'rich harvest', štědrá odměna 'generous reward'). However, most frequently it is used in the collocations Štědrý den

${ }^{14}$ The decision not to celebrate Christmas is understandable e.g. after the death of a family member. According to psychologists, Christmas is a very difficult period for people suffering from depression, for those in a relationship crisis, for people experiencing a loss etc. At this time, family conflicts, inner troubles, or feelings of loneliness intensify significantly. One of the reasons for this is that it is not possible to meet the expectations and requirements of the stereotypical Christmas, often promoted by the media ("Christmas is a family holiday", "Nobody should be alone during Christmas" etc.). In these cases, it becomes even more difficult to deal with one's personal problems.

15 The other two Christmas days are associated with fewer rituals, with the festive nature of the Christmas Eve fading away. For most Czechs (who are not religious), these are relaxed days of "well-being", family visits, walks, and cultural events (Christmas concerts, exhibitions etc.). 
and Štědrý večer $\left(24^{\text {th }}\right.$ December, Christmas Eve $-{ }^{*}$ Generous Day, ${ }^{*}$ Generous Eve). The adjective štédrý is one of the old pagan expressions that changed their meaning completely with the arrival of Christianity. According to Machek, the Proto-Slavic * ščedro originally meant "somebody who spends wastefully, wastes something needlessly, e.g. hay, straw etc., [...] so that much is wasted in vain". Due to the shift in meaning, "this word was later used in the moral sense as the opposite of greediness [...] representing 'mercifulness' unknown to pagans" (Machek 1997). Following Machek, Němec and Horálek add: "giving money and things to undeserving or bad people, previously thought to be a waste, became an act of mercy". In old Czech texts, these two adjectives štědry' 'generous' and milosrdny "merciful" co-occur, often as a characteristic of the first day of Christmas (Němec, Horálek et. al. 1984: 351).

Respondents ${ }^{16}$ repeatedly state that Christmas Eve is the most special day of the year. This is most apparent in children getting increasingly excited about Christmas Eve and counting the days "till Ježršek/the Baby Jesus arrives". Even today, in our secularized society, the sacrum dimension is still preserved in Christmas, despite the fact that Czechs are said to be the most atheistic nation in Europe, that they rarely experience time in accordance with the Christian year, and that in recent years they have been significantly abandoning their rituals (especially funerals). In Christmas, however, many customs and rituals are still preserved (albeit transformed or variously travestied). ${ }^{17}$

According to various surveys as well as general knowledge, there are numerous variations to the Christmas Eve scenario in Czech and Moravian families. However, regardless of their age, region, education, or social status, their members do share a number of specific customs. For example, weeks before the holiday, they start baking various kinds of traditional Christmas cookies with typical names, such as vanilkové rohličky 'vanilla

${ }^{16}$ The author has so far collected more than thirty descriptions of family celebrations of Christmas from students of Czech language and literature (from Charles University in Prague). Her aim is to analyse, at least on a basic level, "the scenario of Christmas celebration" (including preparations prior to Christmas). However, this paper mentions only a few aspects of the Christmas scenario. For similar research focused on children respondents from South Moravia, see Navrátilová (2003).

${ }^{17}$ One of the pre-Christmas rituals is sending Christmas cards, in electronic or paper form, to friends and family. What is interesting is that many relationships between acquaintances or distant relatives are preserved mainly or sometimes solely via sending the Christmas cards. The fact that this tradition of sending cards is significant can be demonstrated in sentences such as "Auntie has not sent us a Christmas card this year, is she all right?"; "We are in touch with our aunt only during Christmas"; "He grew up in a children's home, his mother did not even bother to send him a Christmas card". 
rolls', vosí hnizda 'wasp nests', medvědi tlapky 'bear claws'. There are many shared features of the Christmas Eve dinner as well, especially regarding the recipes, customs, and the process of dining. The main dish is usually battered carp (lately also other kinds of fish, or even chicken or pork schnitzel) with potato salad, sometimes fish soup or wine sausage, or various traditional regional specialities, such as green pea soup, dishes from wild mushrooms or dried fruits etc. ${ }^{18}$ The dinner usually takes place in a festive manner, in formal clothes, with burning candles and decorations on the table (some respondents stated that they own special kitchenware, cutlery, or tablecloths which they use solely for this annual occasion). The dinner usually starts with a common prayer or a toast, often proposed by the father or the oldest family member, who frequently expresses the wish "to meet again next year". People often remember their late relatives or distant family members. To this day, variants of certain old magical acts, which are documented in the literature and believed to have magical power, are performed at the Christmas dinner table. One of them is putting carp scales under the plate (and later into one's purse), which is supposed to guarantee one enough money in the following year; another is to sit at the table in even numbers or not to leave the table during the dinner. After the dinner, one of the adults rings a bell while exclaiming: "Ježžšek/Baby Jesus has arrived!", whereupon the family gather around the Christmas tree with the gifts underneath. In musical families, this is the moment to play and sing Christmas carols. Many respondents reported that after unwrapping the gifts (which is a family ritual itself), the family watch a fairy tale on TV. ${ }^{19}$ The family members are together, experience the "Christmas wellbeing", i.e. they eat Christmas sweets and enjoy the presents. Some families perform fortune-telling rituals, such as apple cutting (a resulting star-like shape of the apple core indicates health and luck in the following year, whereas the cross-like shape suggests the opposite), floating walnut-shells with candles in the sink with each "boat" representing one member of the

18 There is also a related tradition, which is either observed or at least talked about, that those who would fast during the day on December 24, would see "gold pigs on the wall", see Erben's (2013) poem above. The "gold pig" represents an old solar symbol (see Vavřinová 2002: 159) and to this day, Czechs associate it with Christmas. There are chocolate figures shaped like gold pigs, the symbol frequently appears in Christmas commercials etc.

${ }^{19}$ According to various sources (including the respondents as well the author's knowledge), among the most popular are the Czech fairy tale Tři ořišky pro Popelku "Three Wishes for Cinderella" or new fairy tales that are shot and premiered by the main TV stations every year. 
family, or pouring lead and telling the future from the resulting shapes. ${ }^{20}$ The evening often ends with attending midnight mass, even by people who otherwise do not go to church during the year. Today, the schedule of the Christmas Eve is frequently influenced by the TV:

... The schedule is important. First the meal and then the fairy tale on TV. We unwrap the gifts if there is time. If the dinner is finished early and we have at least an hour before the film begins, we can start unwrapping the gifts. But once the fairy tale starts, we have to sit still. That is how it works at grandma's. [...] We do not observe the traditions like pouring lead, floating walnut-shells, or apple-cutting. But I remember that we did all this when I was little. I think we will restore the traditions once there are new children in the family. In the past years, our motto has been that Christmas should be peaceful in the first place. Regarding the Midnight Mass, we rarely make it, usually we are all asleep at midnight, but once or twice we did manage to go there. (respondent Ilona, 22 years, 2013)

The ritual of celebrating Christmas Eve usually takes place in the closest family circle (parents, children, sometimes grandparents). Certain variants of the ritual occur when parents are separated or divorced; until they reach adulthood, the children celebrate Christmas in both families, usually with a similar scenario. Sometimes there is a "second" Christmas celebration on Christmas Day with grandparents or in a partner's family. Celebrating Christmas together for the first time (in a new household or with a small child) is considered a big step for a couple or newlyweds as well as for their families. Especially sad is the first Christmas after the death of a beloved family member. The necessity to spend Christmas Eve without one's family, after a divorce, due to imprisonment or hospitalization, is perceived very negatively; work shifts on Christmas Eve are usually assigned to those without a family. During Christmas, everyone wants to be "with their folks"; Christmas is undisputedly considered a holiday of home and family (rather than a primarily religious holiday).

\section{Social discussion of Christmas. The "ideal" and "real" Christmas. Popular songs}

\section{Save Baby Jesus}

From that foreign no-good fatso

Save Baby Jesus

He's the Christmas symbol, that's so

${ }^{20}$ For the Christmas customs (or rather the Christmas magic) cf. e.g. Vavřinová (2002: 224); for fortune telling within the context of magic semiotics cf. Vaňková (2011). Today, however, the fortune-telling practises are perceived as a form of game or entertainment. 
True he's part of us

We're part of him

Till we bite the dust

He heals our

Spirits grim

Vilém Čok, Zachraňte Ježžška "Save Baby Jesus", a song composed for a campaign of the same name. Translated by Ondřej Hanus for the purpose of this paper. See also www.youtube.com/watch?v=BQ2H1yPvsyo

And Christmas comes again, and everybody's trying,

to buy the sold-out stuff that's not even worth buying,

to grab at least the Star of Bethlehem from the sky,

oh, Christmas comes again, the oblivion time...

Jan Burian, 1997, Předvánoční koleda "The Carol Before Christmas". Translated by Ondřej Hanus for the purpose of this paper. In Jenom zpivám, Praha

To define a word as a key word, Anna Wierzbicka (1997) introduced several relevant criteria, one of them being frequent discussions on the subject that is represented by the key word. These subjects often appear in small talk, social discourse, fiction etc. Vánoce 'Christmas' definitely meets this criterion. Every year, in a reaction to the massive pre-Christmas advertising campaigns, many people criticise the consumerist approach to the Christmas holiday (excessive amounts of food, expensive gifts, material delights, and shopping) and call for a genuine way of celebrating. However, the idea of a genuine celebration differs, preferring either the sacrum experience or the concept POHODA 'well-being' in the family (sometimes, however, these are not necessarily separate). Christmas "well-being" often equals the absence of stress and rush (after the tiring period of preparations), the satisfaction of spending family-time together, and taking delight in gifts and various material pleasures, such as the abundance of food, which is bought and cooked with extraordinary, nearly ritualistic care (baking traditional Christmas cookies and frequent discussions thereof, sharing recipes, etc.). However, the stressful preparations for the holiday (home cleaning and decorating, time-consuming preparations of the Christmas menu, buying gifts for the family) often lead, especially in the case of women, to nervous breakdowns, apathy or family disputes (as reported by many respondents). ${ }^{21}$

Around Christmas, women's magazines and internet chat forums are swamped with discussions about parenting that are indirectly related to the picture of Czech Christmas, such as the phenomenon of sending letters

21 There are posts at various websites that confirm this fact, share personal experience as well as advice on how to handle emotionally difficult family situations during Christmas, cf. www.vitalia.cz/clanky/vanocni-pohoda-i-pres-mrtvoly/; http:// zoufalemaminky.cz/vanocni-pohoda/ 
to Ježišsek 'Baby Jesus' or the questions of how and when the truth about gift-giving should be revealed (that "Ježršsek actually does not exist" and that it is the parents who give them gifts). These sources provide interesting research data: spontaneous discussions, opinions, memories, and stories associated with various Christmas-related topics. ${ }^{22}$

A controversial dimension of today's Christmas is not only its commercialization, but also its globalization. The possibility of Ježršek being replaced by Santa Claus (and before that, during the Communist era, by the Russian Father Frost) has been stirring strong emotions. However, this seems not to have happened yet (even though children often imagine Ježžšek as a bearded old man dressed in red rather than a small child). The initiatives of different organizations seeking to restore Czech traditions, including the Facebook campaign Zachrañte Ježršš ("Save the Baby Jesus"), clearly show how deeply the Czech concept of Christmas and Ježžšek is rooted in Czech culture, eo ipso in Czech families and in the minds of Czech people. ${ }^{23}$

The project entitled Zachrañte Ježźška was launched in 2008 as a student event to support traditional Czech Christmas, and it has been going on ever since. Its aim is to open social discussion on the internet and on Facebook about integrating international customs into Czech traditions. It includes a petition that is signed by tens of thousands of people every December. The campaign usually culminates in a parade of snowmen, which symbolically present the petition to the Czech Prime Minister and government.

The present picture of Christmas in the Czech language (including the "language" of the traditional customs and rituals) suggests that Christmas represents very significant values for all generations of Czech speakers. The evocation and linguistic reflection of this holiday shows that even today, Czechs need to experience the sacrum and enter into, however scarcely, the magical picture of the world. The present picture of Christmas combines hedonism, which is confirmed by the lifestyle of a consumerist society (desire for comfort, "well-being", material satisfaction, and luxury), with the sacrum experience, which is based not only on the birth of Jesus Christ (Ježžšek)

22 See http://zena.centrum.cz/deti/batolata-a-predskolaci/clanek.phtml?id $=765462$ etc.

${ }^{23}$ Aside from raising awareness about traditions, these initiatives frequently have a commercial character, too. In the Boží Dar village, described on their website as "The small town of Ježišsek 'Baby Jesus' in the heart of the Ore Mountains", there is a tourist attraction for children called Ježřškova cesta "Ježíšek's path", and since 1994, there has been the Ježiškova pošta "Ježíšek's Post Office" in operation, where both children and adults can send their letters to Baby Jesus (see http://www.bozi-dar.eu/cz/jeziskovacesta). 
and Christian values, but also on home, family, traditions, childhood, and remembering one's roots.

In the Czech picture of the world, Christmas represents an extremely positive period offering the most valuable human experience. The fact that it can be perceived and conceptualized in other ways as well simply shows that there are other possible variations to the Christmas stereotype, which actually confirm its essence. An important work in this context is the monograph České Vánoce od vzniku republiky do sametové revoluce "Czech Christmas from the First Republic to the Velvet Revolution" (Kourovi 2010), which contains extensive authentic data on Christmas celebration in modern history in both Czech families and common households as well as in non-standard conditions, to which e.g. political prisoners in Nazi and Communist regimes were subjected.

The chapter on the celebration of Christmas during the era of Normalization is titled Svátky zapomnění "The Oblivion Time", the inspiration being a song by Jan Burian (see above). Its critical lyrics reflect the air of hopelessness prevailing during this time, which was caused not only by the political situation, but also by general apathy, indifference, and loss of human values. During the Communist era, it was not exceptional for singers-songwriters to conceptualize Christmas in this manner.

Let us now focus on the field of popular songs, where the atmosphere and specific values of an era are reflected very vividly. As for research into the linguistic worldview, popular sources are an excellent source of data. In recent decades, a number of Christmas-themed songs appeared that deserve a deeper analysis. Two of them, both composed by coincidence in 1962, have to this day remained an integral part of Czech Christmas. According to the historians Petr Koura and Pavlína Kourová, the first one represents a celebration of a consumerist and absolutely non-spiritual concept of Christmas (Kourovi 2010: 255), but it needs to be said that this song more likely tries to mock certain typical attributes of Christmas (although it remains unclear whether contemporary listeners perceive it that way). This song is titled after its catchy refrain Vánoce, Vánoce přicházeji "Christmas Coming". The lyrics by Zdeněk Borovec describe humorous Christmas mishaps from the perspective of a child (while being performed by an actual child singer), such as poorly baked Christmas bread, a Christmas tree catching fire, a fish bone getting stuck in someone's neck during the Christmas Eve dinner etc. The final verse of the song summarizes Christmas in an apt manner:

After dinner we're no thinner, then it's blessed TV time

I'm all "yippee!", they're all sleepy, now everything's fine.

I'm getting, too, slowly into sleep mode, I've had too much fun. 
No more stress now, no more mess now - till the next year comes

Zdeněk Borovec, Vánoce, Vánoce přicházejı "Christmas Coming", translated by Ondřej Hanus for the purpose of this paper. See Kourovi 2010: 255

The other song, titled Purpura "Christmas Frankincense", is just as wellknown. Its name refers to a type of frankincense that is put on a hot stove to release its scent. This song is a poetic depiction of the transcience of ceremonial moments. For most Czechs, this song is an embodiment of Christmas from its very first notes.

Silently, oh, sweet scents rising from frankincense

Rising, slowly rising

Nobody notices life slowly burning away

Maybe just somewhere far foolishly poets are

Crying, for it's dying

They will toll bells for it in the ice chapel one day...

Jiří Suchý, Purpura "Frankincense". Translated by Ondřej Hanus for the purpose of this paper. Písničky 6, Pra - Ti. Praha: Karolinum - Pražská imaginace, 2001: 58

In the introduction, it was stated that "Vánoce" is a specifically Czech holiday. Part of this specificity results from the contexts that popular songs help to create. In other words, the picture of Christmas (with all its variations) is evoked and at the same time confirmed by the fact that (during the time) before Christmas, Czechs sing and listen to new versions of old Christmas carols as well as Christmas-themed popular songs similar to those mentioned above.

\section{The picture of Christmas in Czech sign language (initial notes)}

Recently, our objective has been to establish whether the methodology of cognitive-ethnolinguistic research can be applied to the analysis of stereotypes in (Czech) sign language. The nature of a sign language significantly differs from that of a spoken language: it is realized via a visual-motor system, it is firmly based on the principle of iconicity, it does not have a written form etc. (see Macurová 2001). Many studies from cognitive linguistics of sign languages focus on metaphor and metonymy or on the issue of double-mapping (Taub 2001; Wilcox 2007; for Czech, see Šůchová 2011). This term refers to the fact that metaphorical and metonymical mapping is always linked to iconic mapping in sign languages. We have also been trying to confront these ideas with Bartmińsky's theory and methodology (cf. Bartmiński 2007, 2009). 
As of this moment, we can only present initial notes on the picture, or rather the stereotype, of Christmas in Czech deaf community. Our hypothesis is that the form of a sign - i.e. its motivation or etymology - may indicate which aspect or feature is the basis on which a given phenomenon is conceptualized in the sign (in our case Christmas), i.e. what its stereotype is. ${ }^{24}$ In our opinion, the motivation of a sign can show what it is (or was) that the Czech deaf community deemed so important and significant that it became a basis for the conceptualization of the phenomenon (both in the mind and) in the language of the community. ${ }^{25}$ This is the case for several "Christmas" signs that we analyse below. The nature of the conceptualization is iconic-metonymic. For illustration, we have used the first Dictionary of the Czech Sign Language, $S Z \check{R}$ (however imperfect), as it simplifies the information (which is useful for our purposes).

The photography of the sign for VÁNOCE is accompanied by the following description: "The lowered palms draw a Christmas tree shape in front of the body" ( $S Z \check{R}$ 1988: 260). There is also another, Moravian version of the VÁNOCE sign connecting Christmas with fish (indicated by a wiggling right hand imitating the movement of a fish tail). Similar conceptualization with reference to fish, or carp as an important part of the Czech concept of Christmas - appears in the case of the twelfth month of the year, see the dictionary entry for PROSINEC 'December': "finger tips are wiggling (like a carp's tail)" ( $S Z \check{R}$ 1988: 177). To sum up, December is conceptualized (in the process of iconic and double metonymical mapping) using fish, which is an integral part of the complex Czech concept of VÁNOCE (fish $\leftarrow$ fish as a part of Christmas $\leftarrow$ Christmas as a part of December).

Another interesting sign refers to the Štědrý den 'December 24'. The ŠTĚDRÝ DEN sign is articulated (with the addition of the speech com-

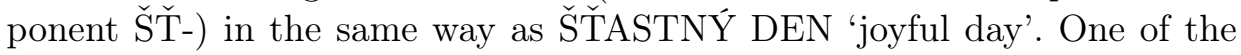
reasons is the fact that both adjectives start with the same pair of distinctly articulated letters; however, it also implies very pleasant connotations associated with Štědrý den (as it is štastný 'joyful', too). As a matter of fact, Czech texts, older and contemporary, along with the questionnaire answers from both Czech and Moravian respondents prove that "Štědrý den is the most beautiful day of all three hundred and sixty five days in a year". ${ }^{26}$

${ }^{24}$ Etymology, or motivation of expressions associated with a given concept, is crucial for the study of stereotypes in spoken languages as well, along with other systemic data, such as semantic and morphological derivates, phraseology etc.

${ }^{25}$ Frequently, the motivation is unclear (or obliterated by arbitrariness), such as in the case of spoken languages. Sometimes, however, the iconicity is so apparent that it can be noticed even by non-scholars, or understood if explained.

${ }^{26}$ A thirteen-year-old girl from Brno, see Navrátilová (2003: 192). 


\section{References}

Abramowicz Maciej, Bartmiński Jerzy, Bielińska-Gardziel Iwona (eds.), 2012, Wartości $w$ językowo-kulturowym obrazie świata Stowian i ich sasiadów 1, Lublin: Wydawnictwo UMCS.

Bartmiński Jerzy, 2007, Stereotypy mieszkaja w języku. Studia etnolingwistyczne, Lublin: Wydawnictwo UMCS.

Bartmiński Jerzy, 2009, Językowe podstawy obrazu świata, $3^{\text {rd }}$ ed. Lublin: Wydawnictwo UMCS.

Bartmiński Jerzy, 2010, Jaké hodnoty spoluutvářejí jazykový obraz světa Slovanů?, „Slovo a slovesnost" 71 (4): 329-339.

Brouček Stanislav, Jeřábek Richard (eds.), 2007, Lidová kultura. Národopisná encyklopedie Cech, Moravy a Slezska 1-3, Praha: Mladá fronta.

Burian Jan, 1997, Předvánočni koleda, [in:] Jenom zpivám, Praha.

Český národni korpus - SYN2000. Ústav Českého národního korpusu FF UK, Praha 2000, dostupný z WWW: http://www.korpus.cz

Danaher David S., 2010, Translating Havel: Three key words (domov, svědomi, and klid), „Slovo a slovesnost" 71 (4): 250-259.

Eliade Mircea, 2006, Posvátné a profánní, Praha: Oikúmené.

Erben Karel Jaromir, 1937, Prostonárodni české písně a ř́kadla, Praha: Evropský literární klub.

Erben Karel Jaromir, 2013, Štědrý den / Christmas Eve, [in:] Kytice / Wild Flowers. Czech and English bilingual edition, translated by Susan Reynolds, Great Britain: Jantar Publishing.

Frolec Václav (ed.), 1988, Vánoce v české kultuře, Praha: Vyšehrad.

Holan Vladimír, 1988, Noc s Hamletem / A Night with Hamlet, translated by Clayton Eshleman, [in:] C. Eshleman, A. Smith, F. W. Galan (eds.), Conductors of the Pit: Major Works by Rimbaud, Vallejo, Césaire, Artaud and Holan, New York: Paragon House.

Janda Laura A., 2007, From Cognitive Linguistics to Cultural Linguistics, „Slovo a smysl” 8 (IV): 69-83.

Janáčková Jaroslava, 2001, Př́běh tajemného psaní. O pramenech a genezi Babičky, Praha: Akropolis.

Jungmann Josef, 1989, Česko-německý slovnik Josefa Jungmanna (I-V, 1835-1839), Praha: Academia.

Kourovi Pavlína a Petr, 2010, České Vánoce od vzniku republiky po sametovou revoluci, Praha: Dokořán - Máj.

Lakoff George, Johnson Mark, 2008 [1980], Metaphors We Live By, Chicago: University of Chicago Press.

Lotman Jurij M., 1990, Śtruktúra umeleckého textu, Bratislava: Tatran.

Machek Václav, 1997, Etymologický slovnik jazyka českého, Praha: Nakladatelství Lidové noviny.

Macurová Alena, 2001, Jazyk a hluchota, „Slovo a slovesnost” 62: 92-104.

Navrátilová Alexandra, 2003, ... jak slaví i jiné svátky, [in:] Rajče na útěku. Kapitoly o kultuře a folkloru dnešních děti a mládeže s ukázkami, 185-214, Brno: Doplněk.

Němec Igor, Horálek Jan et al., 1984, Dědictví řeči, Praha: Panorama.

Prudký Libor et al., 2009, Inventura hodnot: Výsledky sociologických výzkumů hodnot ve společnosti České republiky, Praha: Academia. 
PSJČ 1935-1957, Příručni slovník jazyka českého, I-IX, Praha: Česká akademie věd a umění - Československá akademie věd. (http://bara.ujc.cas.cz/psjc/).

Rejzek Jiří, 2001, Český etymologický slovnik, Voznice: Leda.

SSJČ 1958-1971, Slovník spisovného jazyka českého, I-IV, Praha: Nakladatelství Československé akademie věd. (http://ssjc.ujc.cas.cz/)

SSČ 1994. Slovník spisovné češtiny pro školu a veřejnost, vydání druhé, revidované, Praha: Academia.

SsoučČ 2011, Slovnik současné češtiny, Praha: Leda.

SŽ̌ 1988, Slovník znakové řeči, Dagmar Gabrielová, Jaroslav Paur, Josef Zeman, Praha: Horizont.

Šủchová Lucie, 2011, Znakové jazyky: a kognitivní lingvistika: problematika konceptuálních metafor, „Jazykovědné aktuality” XLVIII, č. 1-2: 5-15. (http://www.ujc.cas. $\mathrm{cz} / \mathrm{js} / \mathrm{jaz} \_$akt.htm)

Taub Sarah, 2001, Language from the Body: Iconicity and Metaphor in American Sign Language, Cambridge: Cambridge University Press.

Tolstoj Nikita I., 2003, Vremeni magičeskij krug, [in:] N. I. Tolstoj, Očerki slavjanskogo jazyčestva, 27-36, Moskva: Indrik.

Váňa Zdeněk, 1990, Svět slovanských bohů a démonů, Praha: Panorama.

Vaňková Irena, 201, Bud'te v pohodě! (Pohoda jako české kličové slovo), [in:] Vaňková I., Pacovská J. (eds.), Obraz člověka v jazyce, 31-57, Praha: Univerzita Karlova - Filozofická fakulta, ÚČJTK.

Vaňková Irena, 2011, Přichyl ucho $k$ zemi blǐz. Erbenova Kytice a sémiotické principy magického obrazu světa. Z Českého ráje a Podkrkonoši, Supplementum 14, Karel Jaromír Erben a úloha pamětových instituci v historických proměnách. Referáty $z$ vědecké konference konané ve dnech 15.-16. dubna 2011 na Malé Skále, 2, díl. 46-65, Semily-Turnov.

Vaňková Irena, 2012a, DŮM i DOMOV v češskoj jazykovoj kartine mira, [in:] Maciej Abramowicz, Jerzy Bartmiński, Iwona Bielińska-Gardziel (eds.), Wartości $w$ językowo-kulturowym obrazie świata Stowian i ich sąsiadów 1, 69-88, Lublin: Wydawnictwo UMCS.

Vaňková Irena, 2012b, $\check{R}$ a pohoda domova. Glosy o češtině a českém obrazu světa ve světle klǐčových slov, [in:] $\check{R}$ ! Česká národní identita v současném umění. Katalog $k$ výstavě v Galerii Vysoké školy uměleckoprůmyslové v Praze, 59-66, Praha: Vysoká škola uměleckoprůmyslová.

Vaňková Irena, Forthcoming, Vánoce jako kličové slovo české kultury. (První poznámky k etnolingvistickému výzkumu), „Didaktické studie”.

Vavřinová Valburga, 2002, Malá encyklopedie Vánoc, Praha: Libri.

Večerková Eva, Frolcová Věra, 2010, Evropské Vánoce v tradicích lidové kultury, Praha: Vyšehrad.

Wierzbicka Anna, 1997, Understanding Cultures through Their Keywords. English, Russian, Polish, German and Japanese, Oxford-New York: Oxford University Press.

Wilcox Sherman, 2007, Signed Languages, [in:] Dirk Geeraerts, Hubert Cuykens (eds.), The Oxford Handbook of Cognitive Linguistics, 1113-1136, Oxford-New York: Oxford University Press.

Wildová Zuzana, Forthcoming, Obraz Vánoc v českém jazyce a kultuře. Perspektiva kognitivni etnolingvistiky a didaktiky, „Didaktické studie”. 


\section{Czeskie Vánoce 'Boże Narodzenie' W perspektywie etnolingwistycznej (CZESKIE WARTOŚCI I SEOWA KLUCZE)}

Artykuł jest pilotażową próbą etnolingwistycznego opisu czeskiego pojęcia VÁNOCE 'Boże Narodzenie'. Zostaje ono umieszczone w kontekście innych słów kluczy, z odwołaniem do wcześniejszych badań autorki dotyczących pojęć DOMOV 'dom, ojczyzna' i POHODA 'wygoda, komfort, odpoczynek, spokój'. W niniejszej pracy pojęcie to jest opisane zgodnie $\mathrm{z}$ definicjami $\mathrm{w}$ jednojęzycznych słownikach języka czeskiego; uwzględniono także, na podstawie danych empirycznych, rytuały i scenariusze zachowań związane z Wigilią Bożego Narodzenia; poddano analizie dyskusje społeczne na temat świąt (zwłaszcza dotyczące postaci dzieciątka Jezus) oraz przykłady konceptualizacji Bożego Narodzenia w popularnych piosenkach. Artykuł zamykają wstępne uwagi na temat stereotypu świąt w czeskim języku migowym.

SŁowa kluczowe: Vánoce, Boże Narodzenie, wartości, język czeski, kultura czeska, etnolingwistyka kognitywna, kulturowe słowa klucze, czeski język migowy 